\title{
Transient increase of serum Clara cell protein (CC16) after exposure to smoke
}

\author{
Alfred Bernard, Cedric Hermans, Guy Van Houte
}

\begin{abstract}
Objectives-Smoke inhalation is a well known cause of airways injury in firefighting personnel. The aim of this study was to evaluate whether toxic effects of smoke on the respiratory tract can be detected by measuring Clara cell protein (CC16), a recently described serum marker of lung function.

Methods-CC16 was measured by a sensitive latex immunoassay in the serum of six voluntary firefighters from a chemical plant who had inhaled smoke from the combustion of polypropylene for about 20 minutes. The protein was measured immediately after the fire and 10 days later. The values were compared with those of six control workers examined simultaneously.

Results-The mean (SD) concentration of CC16 in the serum of firefighters after the fire $(54.4(34.9) \mu g / 1)$ was significantly higher than that of controls (19.5 (11.7), $P=0.04)$. 10 days later, serum CC16 from firefighters had returned to the concentrations found in controls (15.9 (2.76) $v 17 \cdot 7(12 \cdot 5))$. With the values at day 10 as a baseline, the rise of serum CC16 was estimated at $328 \%$ on average (range $100 \%-564 \%$ ). These changes were found in the absence of any functional sign of lung impairment.

Conclusion-Acute exposure to smoke results in a transient increase of $\mathrm{CC16}$ in serum due most likely to an increased permeability of the bronchoalveolar / blood barrier. Serum CC16 seems potentially to be a new biomarker for the early detection of acute airways injury caused by smoke.
\end{abstract}

Unit of Industrial Toxicology and Occupational Medicine, Catholic University of Louvain, 30.54 Clos Chapelleaux-Champs, B-1200 Brussels, Belgium A Bernard

C Hermans

G Van Houte

Correspondence to: Professor A Bernard, Unit of Industrial Toxicology and Occupational Medicine, Catholic University of Louvain, Faculty of Medicine, 30.54 Clos Chapelle-aux-Champs, B-1200 Brussels, Belgium. Accepted 29 July 1996

(Occup Environ Med 1997;54:63-65)

Keywords: smoke; Clara cell protein; lung toxicity; biomarker of effect

Acute airways injury is an important occupational hazard for firefighting personnel. Combustion and pyrolysis generate a wide variety of irritants (nitrogen and sulphur dioxides, aldehydes, halogenated hydrocarbons) which can cause direct toxicity to the respiratory tract. Early diagnosis of injury from smoke inhalation relies essentially on symptomatology and on pulmonary function tests. ${ }^{12}$ Obstructive ventilatory defects after acute exposure to smoke are well documented and are recognised as the earliest signs of lung toxicity induced by smoke. ${ }^{134}$ There is presently no biochemical test to assess the extent of airways injury in victims of smoke inhalation nor to monitor firefighters regularly exposed to smoke.

Recently, a new lung biomarker, measurable not only in bronchoalveolar lavage fluid but also in serum has been described. ${ }^{5}$ This biomarker is a $16 \mathrm{kD}$ microprotein (CC16) secreted by the Clara cells, which are nonciliated epithelial cells predominantly occurring in terminal and respiratory bronchioles. The CC16 has several features which make it a potentially interesting marker of toxicity. It is the major secretory product of a lung cell type that increasingly seems to be an important mediator in the development of lung injury, both as a target cell and as a progenitor cell for regeneration of the epithelium. The exact function of $\mathrm{CC} 16$ is still unknown but evidence is accumulating that the protein could protect the respiratory tract by exerting regulatory control over inflammatory reactions and fibroblast chemotaxis. Of special interest for occupational and environmental medicine, CC16 seems to be the first lung specific biomarker measurable in easily accessible biological media such as serum. Owing to its small size, CC16 secreted into the respiratory tract can indeed readily diffuse into serum where it may serve as a peripheral marker of bronchial cell injury. Although $\mathrm{CC} 16$ is also secreted by the male urogenital tract, the lung seems to be the predominant if not the exclusive source of serum $\mathrm{CC} 16.56$

We report here that serum $\mathrm{CC} 16$ can be used for detecting early changes in the permeability of the bronchoalveolar / capillary barrier caused by smoke or other lung irritants.

\section{Materials and methods}

SUBJECTS AND EXPOSURE

The study was carried out on six voluntary firefighters who were members of the first intervention team in a chemical plant. They were aged 27 to 49 years (mean 38.2 years). Three of them were never smokers, two were ex-smokers, and one was a smoker. They were exposed to smoke from the combustion of polypropylene for about 20 minutes. Combustion of this material can result in the emission of various low molecular weight oxygenated compounds including potent lung irritants such as formaldehyde and acrolein. ${ }^{7}$ The 
control group was composed of six workers, aged 30 to 53 years (mean 46 years), and comprised five never smokers and one current smoker. An additional control group was also examined to study the diurnal variations of serum CC16. The group included seven healthy subjects (one woman and six men) from the laboratory staff, aged 24 to 43 years. Six subjects were never smokers and one was a smoker.

\section{METHODS}

Each subject provided a sample of $10 \mathrm{ml}$ venous blood. Blood samples were collected in dry tubes and immediately transferred to the laboratory where the serum was separated and stored at $4^{\circ} \mathrm{C}$ until analysis. Samples from firefighters were collected between 30 and 60 minutes after the fire. A second sample was collected 10 days later. Samples from controls were taken and processed by the same protocol.

The concentration of $\mathrm{CC} 16$ in serum was measured by a sensitive immunoassay relying on the agglutination of latex particles. ${ }^{8}$ The assay uses the antiprotein 1 antibody from Dakopatts (Glostrup, Denmark) and, as standard, the protein purified in our laboratory. ${ }^{9}$ The analysis was carried out in duplicate on two different dilutions of the serum $(\times 40$ or $x 80$ ). The minimum volume of serum required for the assay is $0.5 \mathrm{ml}$. The immunoassay has a detection limit of $0.125 \mu \mathrm{g} / \mathrm{l}$. As the lowest dilution for an accurate measurement of the protein in serum is $\times 20$, this corresponds to a practical limit of detection in serum of $2.5 \mu \mathrm{g} / 1$. Variations within and between runs were $5 \%$ and $10 \%$. A similar assay was used for the measurement of serum $\beta_{2}$-microglobulin. ${ }^{10}$

\section{STATISTICAL ANALYSES}

Comparison between exposed and control subjects was done by the Student's $t$ test (paired or unpaired) after log transformation of the data. The influence of sampling time on the serum concentrations of CC16 in controls was assessed by one way analysis of varience (ANOVA) (repeated measures). Results are given as the arithmetic mean (SD). The level of significance was set at $\mathrm{P}<0.05$.

\section{Results}

Five of the firefighters had complaints of airways irritation after the exposure to smoke. Clinical examination was, however, normal for all firefighters in whom no decrement in lung function was detected. Their mean vital capacity (VC) was $4.49(1 \cdot 26) 1(99 \cdot 7 \%(22 \cdot 1 \%)$ of predicted values) and their mean forced expiratory volume in one second $\left(\mathrm{FEV}_{1}\right)$ was 3.87 $(1 \cdot 19) 1(94 \cdot 7 \%(18 \cdot 4 \%)$ of predicted values). The $\mathrm{FEV}_{1} / \mathrm{VC}$ ratio averaged $85.6 \%(4 \%)$ and did not differ from that of the pre-employment examination $(82.6 \%(5 \cdot 6 \%))$ which took place seven to 26 years before.

The concentration of serum $\mathrm{CC} 16$ found in firefighters immediately after the fire was significantly higher than that of controls exam-

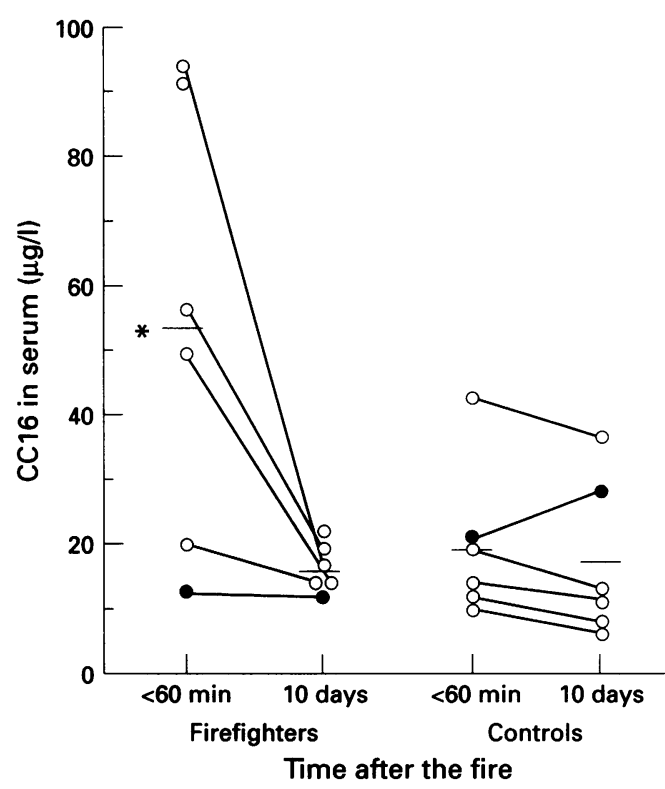

Concentration of CC16 in the serum of firefighters and their controls, 30 to 60 minutes after exposure to smoke and 10 days later. *Significantly different from control values. Closed symbols correspond to current smokers.

ined simultaneously (figure). Ten days later, however, values of serum CC16 of all firefighters had returned to normal. If the values at day 10 are used as basal level, the mean (range) rise of serum CC16 in firefighters can be estimated at $328 \%(100 \%-564 \%)$. No difference was found in the serum concentration of $\beta_{2-}$ microglobulin between firefighters and controls, immediately after the fire $(2.04(0.6) v$ $1.99(0.47) \mathrm{mg} / \mathrm{l})$ or 10 days later $(1.77(0.39)$ $v 1.76(0.5) \mathrm{mg} / \mathrm{l})$. The low number of subjects precluded any search for possible associations between the peak of serum CC16 and factors such as smoking or age.

We checked that these changes were not simply due to diurnal variations by measuring CC16 in the serum of seven healthy volunteers collected between 900 and 1000 am, 130 and $230 \mathrm{pm}$, and 400 and $530 \mathrm{pm}$. The coefficient of variation calculated for each subject ranged from $5 \cdot 5 \%$ to $23.9 \%$ (mean $11 \cdot 4 \%)$. No significant difference was detected by ANOVA between the three sets of means (SDs) $(16.7(5.4), 14.3(3.7)$, and 14.5 (3.9) $\mu \mathrm{g} / 1$, respectively).

\section{Discussion}

This study shows a transient increase of serum CC16 after a short exposure to smoke. This increase is much too obvious to be ascribable to variations within people. On the basis of our current understanding of $\mathrm{CC} 16$ metabolism, the most plausible explanation for this effect is an increased leakage of the protein from its main production site, the respiratory tract. The rapidity of the increase makes the hypothesis of a stimulated production of the protein unlikely but leakage as a transient disruption of the bronchoalveolar / capillary barrier is more likely. Animal studies have shown that bronchial epithelial cell injury caused by smoke is associated with an 
increased permeability of the bronchoalveolar/ capillary barrier to plasma proteins such as albumin. ${ }^{711}$ If the transcapillary escape of albumin can be enhanced, it can be logically assumed that this should be also the case-but in the opposite direction-for proteins, and especially of CC16 derived from the lung, the passage of which is facilitated by its small size and a huge concentration difference between blood and the fluid of the epithelial lining (more than three orders of magnitude). ${ }^{5}$ This interpretation is supported by the finding of increased concentrations of $\mathrm{CC} 16$ in the serum of patients with lung diseases in whom the integrity of the bronchoalveolar capillary / barrier is compromised-for example, sarcoidosis. ${ }^{5}$ Other mechanisms that might explain the peak of serum CC16 would be an increased haemoconcentrations or a reduced renal clearance but obviously such mechanisms cannot account for the magnitude of the changes found (up to a fivefold increase); in any case they can be formally ruled out in view of the lack of changes in the serum concentrations of $\beta_{2}$-microglobulin.

Clara cells are very sensitive to lung irritants. It has been shown for instance that the surface structure of Clara cells is very rapidly damaged after exposure to ozone. ${ }^{12}$ Experimental studies have shown that acute destruction of Clara cells results in reduced production or secretion of CC16 in the respiratory tract which is mirrored by the serum concentrations. ${ }^{6}$ This mechanism has been proposed to explain the reduction of serum CC16 in cigarette smokers and in workers chronically exposed to crystalline silica. ${ }^{1314} \mathrm{It}$ is probable that this also occurs after exposure to smoke. This would not be incompatible with the peak of $\mathrm{CC} 16$ reported here which reflects a distinct effect-that is, a disruption of the bronchoalveolar / capillary barrier caused by acute inflammatory changes. Animal studies show that these two effects can be associated. In rats, for instance, the acute destruction of Clara cells by 4-ipomeanol results in a notable reduction in the concentration of CC16 in bronchoalveolar lavage fluid and concomitantly in an increase of the protein in serum (Hermans et al, unpublished data). In firefighters, this hypothesis could be tested either by examining basal concentrations of serum CC16 in regular firefighters or by monitoring serum CC16 after an episode of acute exposure. By analogy with similar size proteins, the plasma half life of $\mathrm{CC} 16$ can be estimated at a maximum of a few hours. If toxic effects on Clara cells and on the bronchoalveolar / capillary barrier are temporally dissociated, they might give rise to distinct changes in serum.

Whatever the changes of serum $\mathrm{CC} 16$ and their underlying mechanism, a consistent feature of the CC16 response to toxic injury is its higher sensitivity compared with that of classical diagnostic tests. The effects of serum CC16 reported so far were always found in subjects presenting no significant decrement in lung function. Although this sensitivity might increase our capability to detect exposures to chemicals harmful to the respiratory tract, further studies are necessary to establish the importance to health of changes of serum $\mathrm{CC} 16$ and the usefulness of this new biomarker for monitoring populations at risk.

This study was supported by the Commission of the European Communities and the National Fund for Scientific Research (Belgium). AB is research director of the National Fund for Scientific Research.

1 Haponik EF. Clinical smoke inhalation injury: pulmonary effects. In: Susterman DJ, Peterson JE, eds. Occupational medicine: state of the art review, vol 8. Philadelphia: Hanley medicine: state of the art revier

2 Scannell CH, Balmes JR. Pulmonary effects of firefighting. In: Orris P, Melius J, Duffy R, eds. Occupational medicine: state of the art review, vol 10. Philadelphia: Hanley and Belfus, 1995:789-802.

3 Musk AW, Smith JM, McLauhlin E. Pulmonary function in firefighters: acute changes in ventilatory capacity and their correlates. $\mathrm{Br} \mathcal{F}$ Ind Med 1979;36:29-34.

4 Loke J, Farmer W, Mattay RA, Putman CE, Smith GJ. Acute and chronic effects of fire fighting on pulmonary function. Chest 1980;77:369-73.

5 Bernard A, Marchandise FX, Depelchin S, Lauwerys R, SibilleY. Clara cell protein in serum and bronchoalveolar lavage. Eur Respir 7 1992;5:1231-8.

6 Hermans C, Bernard A. Clara cell protein (CC16): characteristics and potential applications as biomarker of lung toxicity. Biomarkers 1996;1:3-8.

7 Orzel RA. Toxicological aspects of firesmoke: polymer pyrolysis and combustion. In: Susterman DJ, Peterson pyrolysis and combustion. In: Susterman DJ, Peterson JE, eds. Occupational medicine: state of the art review

8 Bernard A, Lauwerys R, Noel A, Vandeleene B, Lambert A. Determination by latex immunoassay of protein 1 in normal and pathological urine. Clin Chim Acta 1991;201 231-46.

9 Bernard A, Dumont X, Roels H, Lauwerys R, Dierynck I, De Ley $M$, et al. The molecular mass and concentration of protein 1 or Clara cell protein in biological fluids: a reappraisal. Clin Chim Acta 1993;223:189-93.

10 Bernard A, Lauwerys R. Continuous flow system for the automation of latex immunoassay by particle counting. Clin Chem 1983;29:1007-11.

11 Lykens MG, Haponik EF, Meredith JW, Bass DA Bronchial epithelial cell damage after inhalation injury Bronchial epithelial cell damage after inhalation injury $12 \mathrm{~S}$.

12 Suzuki E, Takahashi Y, Aida S, Kimula Y, Ito Y, Miura T. Alteration in surface of Clara cells and pulmonary cytochrome $P-450$ level in rats exposed to ozone. Toxicology 1992;71:223-32.

13 Bernard A, Roels H, Buchet JP, Lauwerys R. Decrease of serum Clara cell protein in smokers. Lancet 1992;339: 1620 .

14 Bernard A, Gonzalez JM, Siles E, Trullilano G, Lauwerys R. Early decrease of serum Clara cell protein in silicaexposed workers. Eur Respir f 1994;7:1932-7. 